\title{
Ideas in Science Fiction: Probing Contemporary Contexts through Science Fiction Texts
}

\author{
Shahizah Ismail Hamdan (Corresponding author) \\ School of Language Studies and Linguistics, The National University of Malaysia \\ 43600 Bangi, Selangor, Malaysia \\ Tel: 60-3-8921-6494Ｅ-mail: sha@ukm.my \\ Ravichandran Vengadasamy \\ School of Language Studies and Linguistics, The National University of Malaysia \\ 43600 Bangi, Selangor, Malaysia \\ Tel: 60-3-8921-6559Ｅ-mail: ravicv@ukm.my \\ Noraini Md Yusof \\ School of Language Studies and Linguistics, The National University of Malaysia \\ 43600 Bangi, Selangor, Malaysia \\ Tel: 60-3-8921-6491Ｅ-mail: animy@ukm.my \\ Ruzy Suliza Hashim \\ School of Language Studies and Linguistics, The National University of Malaysia \\ 43600 Bangi, Selangor, Malaysia \\ Tel: 60-3-8921-6481 E-mail: ruzy@ukm.my
}

Received: November 1, 2011

Accepted: December 9, $2011 \quad$ Published: April 1, 2012

doi:10.5539/ass.v8n4p153

URL: http://dx.doi.org/10.5539/ass.v8n4p153

The research is financed by The National University of Malaysia (UKM-PTS-057-2010).

\begin{abstract}
This paper is based on an action research done in an undergraduate class on science fiction. The course, SKBS 2193 Science as Narrative, is part of the BA Literature in English programme at the National University of Malaysia. The objectives of the course are to develop students' communication and critical thinking skills through discussions of different themes within science fiction and to train students to be critical and perceptive to the connection between science fiction and real life issues. This paper demonstrates how studying science fiction helps students become creative and critical thinkers. This is achieved by probing the texts and connecting them to current themes and issues especially those relating to the future of mankind. We also show how the course helps students carry out group projects with outputs in the form of multimedia productions that relate science fiction themes to contemporary issues.
\end{abstract}

Keywords: Science fiction, Literature teaching, Critical thinking, Contemporary issues

\section{Introduction}

Science fiction is a complex literary genre that "resists easy definitions" (Roberts 2000: 1). Sometimes referred to as "speculative fiction", the speculated changes that are dramatised in science fiction "are drawn from, or at least informed by, changes that happen today" (Silvester 2002). However, according to Killian (in Silvester 
2002), as the objective of science fiction is to communicate ideas, not many writers indulge in experimental narrative techniques "and since the ideas in science fiction are concerned with the new and strange, they are best presented within a familiar format". Therefore, to present the subject matters of science fiction that includes aliens, futuristic societies, robots, cyberworlds and other advanced technologies it is important that the ideas are presented in a "commonplace manner" (Silvester 2002) - in that the story must be told in a style that is familiar.

Nevertheless, Darko Suvin, the "elder statesman of SF criticism" (Roberts 2000: 7) defines science fiction as a literary genre that must have "estrangement and cognition" present and "whose main formal device is an imaginative framework alternative to the author's empirical environment" (qtd. in Roberts 2000: 7). The term "estrangement" was made popular by the playwright, Bertolt Brecht, in the 1930's to mean defamiliarisation or alienation. It is a technique that allows us to recognise a subject by making it seem unfamiliar (Roberts 2000; Wolfe 1986). However, Roberts explains that if estrangement is the only defining characteristic of science fiction, then we would not be able to comprehend all that we should. That is why Suvin stresses the importance of cognition "with its rational, logical implications" (qtd in Roberts 2000: 8). Cognition refers to the "elements of variability and detail drawn from the empirical environment that establish a link between the experience world of the reader and the world of the work of fiction" (Wolfe 1986: 18). Cognitive estrangement in science fiction allows us to be estranged from the naturalistic world but at the same time connects us to the world cognitively.

Therefore, science fiction is "a rich genre" and "a cultural phenomenon that encourages an imaginative way of observing and interpreting the world" (Brake and Thornton 2003:31). It explores philosophical and ethical issues in relation to developments in science and technology and provides platforms to discuss and debate on the relationship between man, science, technology and culture. In the West, science fiction as an area of study, made its way into English and/or literature programs in the 1970's (Gunn 1996; Bengels 1996). This was the result of science fiction writers like James Gunn, Jack Williamson, Brian Aldiss, Samuel R. Delany and Joe Halderman joining the literary scholars in the field of literary studies (Wolfe 1986).

According to Gunn (1996), there are three approaches to the teaching of science fiction. The first can be labeled as the "great books" course where the focus is on great Science Fiction novels and their critical analysis. Their "greatness" is also discussed in a course of this nature. The second is what Gunn calls "the ideas in Science Fiction" course. Through this approach, science fiction texts are first deemed as "dramatising" contemporary issues. Then via the science fiction texts, contemporary issues are approached and analysed. The final one is the historical method where texts are studied via the origins and development of the genre. Of concern to this research is the second approach. This method was selected when the course SKBS2193 Science as Narrative was developed for the BA Literature in English Programme at the National University of Malaysia because it is felt that the approach would create a more meaningful teaching and learning context as the fictional creations are made more significant and relevant through critical readings and making connections with real life issues.

Since the introduction of the BA Literature in English Programme in 2009, two cohorts of students have sat for the course. Based on the tutorial discussions, presentations and written assignments of the two cohorts, it is evident that the students found it challenging to relate the works of science fiction to contemporary issues and concerns. They struggled in the meaning making of the estranged science fiction texts and contexts, even though these students were equipped with the skills for literary reading and analysis. The course lecturer spent many tutorial hours explaining the plot, conflict, genre-based concepts and themes to the students. Only then could the students engage in in-depth discussions with regard to the themes, issues and concerns of the texts.

The objectives of this research are to identify and present problems faced by students in understanding science fiction texts, to ascertain problems encountered by students in relating themes and issues in science fiction texts to real life contexts, to establish steps that can be taken to enhance students' understanding of science fiction texts and to suggest modes of input that students require to help them relate themes and issues in science fiction texts to real life contexts.

\section{Methodology}

An action plan was established in order to achieve the objectives of this research which would help achieve the objectives of the course. Firstly, two sets of structured interview questions were prepared and the interviews were carried out with a sample of fifteen students from the third cohort. The first interview was carried out prior to the students sitting for the course and the second was carried out at the end of the fourteen-week semester.

The first interview was designed to obtain a general idea of the students' expectations, assumptions and misconceptions towards the course and the science fiction genre, bearing in mind the students' own awareness as well as influence from the previous cohorts. Following the interview, the students participated in a critical thinking workshop which involved activities that were designed for a general academic endeavour. This first 
intervention, conducted early in the semester, was expected to help develop and hone the students' critical and creative thinking skills. They were then expected to apply the skills to a more specific academic context such as this course. Responses from the first interview were taken into consideration when the course content was put together. The aim of the course was to help students have a more immediate understanding of the selected science fiction texts and their connection to real life issues. The second interview was conducted at the end of the semester to find out whether or not the students' expectations had been met, the problems they faced during the course and if they could suggest ways to make the course better and more interesting.

A limitation to this study is that the design does not include a more objective means of testing the effectiveness of the action plan. This is due to the fact that the evaluation component of the Literature in English Programme is project-based.

\section{Results and Discussion}

\subsection{Expectations, Assumptions and Misconceptions}

The first interview revealed both positive and negative responses by the students. For the positive responses, we found that the students expected to encounter something new, fun and interesting from the science fiction genre that were not offered in other literature courses. They also expected to gain new knowledge and learn how science fiction could have a completely different literary tradition that makes the genre unique. In addition, they expected the course to deal with technology and societal issues that would help them develop critical thinking skills. The responses that could be considered negative in nature revealed that students expected to learn mostly about scientific concepts and theories. This misconception correlated with responses by the students that indicated the perception that they need to have better scientific knowledge in order to understand the content of this course. Whilst some felt that the course would be tough, perhaps even boring, others were confused as they did not know what to expect.

With regard to the students' assumptions about the Science Fiction genre, once again, the responses were positive and negative in nature. The positive assumptions included the students' opinions that the course should be interesting and challenging. The students felt this way because the texts were expected to be highly imaginative and showcase exaggerated possibilities, which in turn could raise awareness of the issues presented within the texts. The negative assumptions about the course included opinions that the course would not be interesting as the genre is about boring subject matters. In addition, some felt that science fiction is specifically for entertainment and not for academic study. Finally, some of these students expressed the assumption that the course would be difficult to understand as the genre of science fiction is all about technology in a modern world, and therefore would be more incomprehensible compared to other genres such as fantasy, mystery or realistic fiction.

One misconception that some of the students had about the course was that they would have to try and accept the "abnormal" things in science fiction in order to prepare for the course. Several even felt that they would have to improve on their grammar and vocabulary to be able to handle the course. On a more positive note, the students reported that they would start reading science fiction texts, researching on the nature of the genre and read up on the writers and their works to prepare for the course. Some even indicated that they would start reading articles on science and technology.

The first interview enabled us to have a better idea of the students' level of knowledge and understanding as well as the pre-conceived notions about science fiction in general, and about the course specifically. This allowed us to make more informed decisions when selecting teaching and learning material and when devising tutorial activities to achieve the objectives of the course.

\subsection{The Course}

The objectives of the course are to develop students' communication and critical thinking skills through discussions of different themes within science fiction and to train students to be critical and perceptive to the connection between science fiction and real life issues. In this course, we also look to address the position of science fiction in today's society to see how science and technology are used to advance and enhance our lifestyles.

In general, the syllabus of the course is designed to facilitate a parallel reading between a science fiction text and a real life issue or theme. Therefore, in relation to studying science fiction as literary texts, students are posited with questions that would relate the texts to contemporary, real life issues. For example, the first text that the students were expected to engage with was the 2008 version of the film The Day the Earth Stood Still. This version was selected over the older one because, firstly, it was felt that the students would relate better to a more 
contemporary film. Secondly, it was also felt that a filmic text would be a softer entry into the course. The theme or real life issue that had to be tackled in this text (film) was human nature. Students were given lead-in questions to help them with their analysis and interpretation of human nature in relation to the text. Some examples of the questions are:

1) Facing impending disaster, what do humans do?

2) Facing unknown phenomena, why do humans approach them with fear/awe/aggression?

3) Note how the politicians/army/scientists reacted. What mentality/ characteristics do they project?

4) Important information is treated as classified by those in power. Why?

5) Leaders immediately felt threatened by the alien race that is seen as more advanced. Why?

As a follow up to the viewing and discussion sessions, students wrote response papers to express their views on the film and the theme of human nature. Some of the students' concluding remarks on the subject matter can be seen in the extracts below:

Extract 1

In a nutshell, "The Day the Earth Stood Still" reveals that the positive qualities of human nature are most likely to crumble when experiencing catastrophe. There are several destructive human characteristics that are clearly portrayed in this film which includes aggression, self-centeredness, dishonesty and greediness. Even though human beings are aware of the destruction happening to the world, yet they still continue to overlook the consequences of their actions. It is rather ironic to have aliens take away and preserve the Earth from humankind when it is humans that should be accountable for the destruction. This film has successfully display the modern media notion of apocalypse in which humans are the cause of catastrophe.

Extract 2

In conclusion, I have given my thoughtful response towards four important elements that are highlighted in "The Day the Earth Stood Still”, they are humanity's self centeredness, man's stubbornness towards changing his own nature, the violence displayed as well as the environmental message of the film. In my opinion, although this film is a work of fiction it contains many important points that are relevant to our modern society. Many of us ignore the fact that the planet is dying due to our actions and it is important that we realize it now before it is too late.

Extract 3

In a nutshell, it is obvious that negative aspects of humankind are prevalent in the film "The Day the Earth Stood Still", yet there is still hope for humanity because goodness is evident as well in human nature. Science fiction's focus isn't about the details of the scientific elements, but rather paying special attention to detail on how humans react in dire situations. This film does an excellent job in portraying the various sides of human nature. Therefore, hopefully those who have been ignorant on how human nature manifests itself can be enlightened on how humans exhibit the various dimensions of human nature.

The extracts above show that the students were able to engage with the film and had successfully linked the themes that were portrayed to real life issues.

Several science fiction short stories were also selected for the course so that students could be provided with an insight into how science fiction deals with various real life issues. To examine issues relating to class and difference, social order and control, and defiance and conformity, we selected Kurt Vonnegut's "Harrison Bergeron" which is categorised under the utopian/dystopian sub-genre. In order to tease out concerns that are relevant to the students' lives, we asked them the following questions:

1) Imagine our world with a society that had total equality. What might be some of the consequences?

2) Would you enjoy living in such a society? Why?

The students also studied Robert Silverberg's "When We Went to See the End of the World" to examine media, commercialism and speculations on the future; Jonna Russ' "When it Changed" and Judith Merril's "Survival Ship" for gender related issues; Severna Park's "The Cure for Everything" for issues relating to developments in genetics and ethics; and James Patrick Kelly's "Itsy Bitsy Spider" to analyse artificial intelligence and how science fiction could be used to study human relationships. The issues were examined by comparing science fiction texts with science facts. Since the students had reported that they expected the course to be tough due to their lack of knowledge of the sciences (in the first interview), the science facts were delivered through varied means. These included interactive lectures, clips from documentaries, film shorts, photographs, newspaper reports and magazine articles. In this way, we were able to keep the students interested and avoid monotony 
during the lesson.

Following the study of the short stories, the students were required to write an essay on any issue related to real life in relation to a Science Fiction short story covered in the course. In addition, the students were asked to produce, in groups of four, a social commentary each in the form of a multimedia-based output on any of the concerns addressed during the course. The multimedia presentations came in the form of short documentaries on topics ranging from "androgeneity in the age of technology" for gender issues, "identity control" for issues relating to social order as well as "hug a tree" that dealt with technological development, ethics and the environment.

\subsection{Problems, Realisations and Suggestions}

At the end of the course a second structured interview was conducted with the same fifteen students. Some of the questions fielded during this second interview were about the students' initial expectations of the course, whether or not the course met their expectations and the reasons for this. Students were also probed about the problems that they encountered during the course and whether or not they enjoyed the learning process. Finally, the researchers asked the students to give suggestions that would help make the course more meaningful and beneficial.

The students' initial expectations of the course included reading stories about aliens, space exploration, robots, science and technology, and learning scientific knowledge in new and fun ways, for example through movies. Some students also expected the course to be boring because they perceived science fiction to be very technical with many technology related jargon and scientific concepts. Others expected it to be interesting, especially the few who had interest in the genre. Some did not expect topics like time travel, artificial intelligence, genetics, and gender related issues.

All students reported that the course met their expectations, with five reporting that the course exceeded their expectations. Asked how the course met or exceeded their expectations, the students said that the course gave them a literary perspective to science. Two students stated that they did not expect that science fiction could be related to social issues, or be used as social commentaries. Generally, the students felt that they were able to learn about the consequences of technology and about human nature. They felt that the course encouraged critical thinking and the discussions had been enjoyable.

The students reported several problems that they faced during the course. A common problem reported by the students was that their unfamiliarity with scientific terms and lack of scientific knowledge made it difficult for them to understand some of the stories in the course (the stories were not specified). One story that dealt with Genetics was particularly problematic since the students had little knowledge or interest in it. The students found some of the stories to be complicated or even intimidating. Three students attributed the difficulty in understanding Science Fiction stories to their lack of interest in the genre. One example that was given was "The Day the Earth Stood Still." One student stated that writing personal responses to these stories were a challenging task, since it required a good imagination and some scientific knowledge. Another student reported that the course was hard to follow for those who were not able to do critical analysis, for analyzing the stories required critical thinking.

There were many aspects of the course that the students enjoyed. In particular, the students liked the analysis of humour and irony in the fiction, the debates on alien encounters, the discussions of various human issues that were present within the stories, and the multimedia social commentary project, lectures and movies. The students were pleasantly surprised to learn that science fiction was not all about science and technology only, and were intrigued by the many ways in which science fiction could teach one about humanity and relate to aesthetics values. Though one student did report that the course was somewhat serious and a little dull, the rest agreed that the course texts encouraged more imaginative thinking compared to romance texts, historical texts, and young adult literature.

As for suggestions to make the course better, the students reported that while they were generally satisfied with the current variety of texts, they felt that the course should include:

1) more critical thinking seminars (one critical thinking seminar was organized as part of the course)

2) fieldwork to make students appreciate science (students could not really specify what they meant by 'fieldwork')

3) some poems, plays and novels from the same genre as part of the course texts

4) other medium that contain science fiction elements, like advertisements 
5) more viewings of science fiction films.

To sum up the interviews, we could say that the general mood of the students prior to the course was one of apprehension and reluctance. The most significant factor that contributed to such an attitude was the students' unfamiliarity to science-fiction being a genre of literary study. The study revealed that as literature students, they felt ill-equipped to handle this genre as they did not have a very strong background in the sciences. As a result, some of the students felt that they would not be able to participate in the tutorial discussions in a satisfactory, critical and analytical manner as required by the objectives of the course. However, after completing the course it was apparent that most of them had changed their outlook towards the course. From being apprehensive in the beginning, they now had a more open-minded and positive outlook towards the genre. To some extent, the course had also succeeded in making the students more critical in their response as they were able to give interesting suggestions to make the course more enjoyable, relevant and meaningful.

\section{Conclusion}

The modes of intervention utilised in the running of the course SKBS2193 Science as Narrative can be categorised under approach, teaching method and assessment. As an approach to the science fiction genre, films were included as "texts" to be studied as well as to serve as sources of reference. These included feature-length films, film shorts as well as short clips. The previous practice was to approach the genre via written texts only such as short stories and novels. Relevant documentaries were also used as means to highlight real life issues in the science fiction texts. For the teaching method, relevant scientific topics, such as 'artificial intelligence' and 'robotics' were introduced before students were asked to study the texts. It was felt that accompanying readings on developments in science and technology would help them see the link between science fiction and contemporary society more clearly. The detailed topic-based discussions conducted during tutorials also helped students to comprehend the texts and issues better. Finally, for the course assessment, a varied mode of assignments ranging from essays to multimedia presentations enabled a fairly accurate evaluation of students' performances while at the same time ensuring that the course remained interesting for the students.

\section{References}

Bengels, B. (1996). The Pleasures and Perils of Teaching Science Fiction on the College Level. Science Fiction Studies, 23(70). Retrieved March 27, 2010, from http://www.depauw.edu/sfs/backissues/70/bengels70art.htm

Brake, M. \& Thornton, R. (2003). Science Fiction in the classroom. Physics Education, 38(1): 31-34. http://dx.doi.org/10.1088/0031-9120/38/1/305

Gunn, J. (1996). Teaching Science Fiction. Science Fiction Studies, 23(70). Retrieved March 27, 2010, from http://www.depauw.edu/sfs/backissues/70/gunn70art.htm

Roberts, A. (2000). Science Fiction. London: Routledge.

Silvester, N. (2002). The More Things Change: Science Fiction Literature and the New Narrative. Strange Horizons. Retrieved April 23, 2011, from http://www.strangehorizons.com/2002/20021125/change.shtml

Wolfe, G. K. (1986). Critical Terms for Science Fiction and Fantasy. A Glossary and Guide to Scholarship. New York: Greenwood Press. 